\title{
A QUESTÃO DO EXÍLIO EM THEODOR ADORNO E PAULO FREIRE
}

DOI 10.26512/Ic.v24i0.19689

\author{
Adilson Cristiano Habowski \\ Universidade La Salle \\ Elaine Conte \\ Universidade La Salle
}

\section{Resumo}

O ensaio discute a questão do exílio e das ideologias totalitários na vida de dois grandes intelectuais críticos, Theodor Adorno e Paulo Freire, que ao manifestarem suas posições de denúncia a explorações e injustiças frente à rigidez do pensar da época, fadaram-se ao exílio. Tais concepções, embora distintas, convergem no caminho esclarecedor do (in)sucesso da experiência formativa pela educação, pois, compreende-se com Adorno, que a educação é uma experiência de reeducação da sociedade administrada, coisificada, enquanto para Freire é uma possibilidade de emancipação política, de autonomia do agir rumo à humanização dialógica e à superação do estado de opressão e alienação pela escola.

Palavras-chave: Theodor Adorno. Paulo Freire. Exílio. Totalitarismos. Educação. 


\section{Resumen}

El ensayo discute la cuestión del exilio y de las ideologías totalitarias en la vida de dos grandes intelectuales críticos, Theodor Adorno y Paulo Freire, que al manifestar sus posiciones de denuncia a exploraciones e injusticias frente a la rigidez del pensamiento de la época, se fadaron al exilio. Las concepciones, aunque distintas, convergen en el camino esclarecedor del éxito de la experiencia formativa por la educación, pues, se comprende con Adorno, que la educación es una experiencia de reeducación de la sociedad administrada, coisificada, mientras que para Freire es una posibilidad de emancipación política, de autonomía del actuar hacia la humanización dialógica y la superación del estado de opresión y alienación por la escuela.

Palabras clave: Theodor Adorno. Paulo Freire. Exilio. Totalitarismo. Educación.

\section{Abstract}

The essay discusses the question of exile and totalitarian ideologies in the lives of two great critical intellectuals, Theodor Adorno and Paulo Freire, who, in expressing their positions of denunciation of explorations and injustices in the face of the rigidity of the thinking of the time, were forced into exile. Such conceptions, although distinct, converge on the enlightening path of the (in) success of formative experience through education, for it is understood with Adorno that education is an experience of reeducation of the managed society, while Freire is a possibility of political emancipation, autonomy of action towards the dialogical humanization and overcoming the state of oppression and alienation by the school.

Keywords: Theodor Adorno. Paulo Freire. Exile. Totalitarianism. Education. 


\section{Résumé}

L'essai aborde la question de l'exil et des idéologies totalitaires dans la vie de deux grands intellectuels critiques, Theodor Adorno et Paulo Freire, qui, en exprimant leurs positions de dénonciation des explorations et des injustices face à la rigidité de la pensée de l'époque, sont contraints à l'exil. De telles conceptions, bien que distinctes, convergent sur la voie éclairante du (in) succès de l'expérience formatrice à travers l'éducation, car Adorno comprend que l'éducation est une expérience de rééducation de la société dirigée, tandis que Freire est une possibilité de émancipation politique, autonomie d'action vers l'humanisation dialogique et dépassement de l'état d'oppression et d'aliénation par l'école.

Mots-clés: Theodor Adorno. Paulo Freire. Exil Totalitarisme Éducation.

\section{Considerações iniciais}

A história nos revela que, quando regimes totalitários e conservadores emergem, grandes pensadores surgem para lutar e resistir criticamente às atrocidades desses sistemas homogêneos e vazios. Essas vozes desabrigadas, errantes e estrangeiras de pensadores que abnegam de suas vidas em prol da defesa da condição humana, da libertação dos oprimidos compreendem que esses sistemas políticos conduzem à degradação, à regressão humana e aos sofrimentos das vítimas. Ao tornarem suas críticas audíveis, fadam-se a dois caminhos ou à morte - por trabalhos forçados, extermínio ou suicídio, ou ao exílio - trancafiados em outros países. Em contextos totalitários, o exílio nem sempre se revela meramente como caminho oposto à morte, já que esse pode significar também a geração de situações patológicas, de armadilhas da experiência frente a uma realidade dura e opressiva que resiste a mudanças.

Se formos olhar o contexto da Segunda Guerra Mundial (1939 a 1945), período em que o totalitarismo nazista conduziu a sociedade alemã à submissão de um ditador fascista, observamos que a humanidade chegou ao ápice da barbárie (Holocausto), tornando-se indiferente à dor e ao sofrimento alheio pela banalidade de uma superioridade racial. Theodor Adorno (1903-1969), por sua voz crítica, inconformista e postura de vertente marxista de consciência do seu tempo resistiu, juntamente com outros teóricos da Escola de Frankfurt, à atitude de adesão da sociedade alemã às atrocidades e ao descaso humano realizado pelo partido nazista. Por isso, o exílio foi o caminho encontrado para não permitir o perecimento de sua voz crítica, revolucionária e de resistência à normatividade da época. Adorno e Freire experienciaram o exílio em locais, períodos, contextos e conjunturas diferentes, mas por viverem e 
compreenderem tal experiência, da qual fizeram parte, desenvolveram suas críticas contra regimes totalitários, advertindo sobre o poder de dominação, manipulação e homogeneização das massas e a identificação cega aos coletivos. Entendemos que ambos apontaram críticas contundentes contra a barbárie humana em conjunturas ditatoriais, provocando resistência às ideias hegemônicas de governo e que devem ser indagadas e ressignificadas no contexto atual.

Nesse cenário, o período da Ditadura Militar (1964-1985) no Brasil representou um período de repressão, perseguição política e censura às posturas socialistas, de esquerda e que defendiam o direito de liberdade e igualdade social. Nesse contexto, os interesses dos militares não estavam em consonância com as necessidades do povo oprimido, mas dos burgueses brasileiros que detinham o poder econômico e se perpetuaram no governo. Os que se mostraram críticos a essa conjuntura opressiva e com olhos voltados aos mais explorados sofreram pelas suas posturas, sendo torturados, presos, condenados à morte ou sendo exilados em outros países. Paulo Freire (1921-1997) foi um dos educadores críticos de vertente socialista que, após algumas prisões porque estava preocupado em desenvolver um programa de alfabetização de adultos no país, não teve outra alternativa a não ser o exílio'

Adorno e Freire, embora oriundos de contextos distintos, apresentam semelhanças nas formas críticas de ver, pensar, sentir e habitar o mundo, sendo exemplos de resistência e de ações reflexivas e revolucionárias de exilados que sobreviveram a realidades opressivas e totalitárias, em defesa de uma educação humanizadora e de luta contra as barbáries humanas. Nessa perspectiva, Adorno passou pela experiência do Holocausto e Freire pela Ditadura Militar, mas com a experiência do exílio geraram influências em seus países de origem e nos países em que se exilaram, influenciando outras gerações para além de seus países de origem. Por mais dolorosa que a experiência de exílio em tempos de conflitos políticos e guerra possa ser, é preciso tomar ciência de que ela proporciona uma ruptura de barreiras e fronteiras que prendem e aprisionam o sujeito em sua própria pátria. Quando Adorno e Freire foram exilados, o ambiente solitário e hostil tornou-se a possibilidade de tomada de distância do território dominado, concedendo assim uma análise crítica mais profunda dos contextos em questão.

Portanto, frente às posturas dos dois intelectuais que tiveram o exílio como refúgio e caminho para manterem vivas suas posturas críticas, lançamos a seguinte problematização da pesquisa: quais as similaridades na formação intelectual dos críticos Theodor Adorno e Paulo Freire que foram exilados de suas pátrias por regimes totalitários? A pesquisa de abordagem hermenêutica visa a interpretar e compreender o exílio de Adorno e Freire como um desígnio do intelectual crítico frente a regimes totalitários, para pensar os destinos de uma educação que possa esclarecer as pessoas e prevenir barbáries coletivas. Trata-se de analisar, pela via hermenêutica, os contextos

1 Dentre outros motivos caluniosos para a perseguição política de Freire estava o fato de que esse professor seria um "perigoso subversivo internacional, um inimigo do povo brasileiro e um inimigo de Deus". Palestra proferida por Freire e disponível em: http://www.youtube.com/watch?v=HIJjgljUj38 Acesso em: 14 jul. 2018. 
dos exílios dos dois pensadores que foram deportados por suas posturas consideradas hostis e de implicações nefastas ante aos modelos centralizadores, inclusive dos sistemas de ensino da memória cultural da época.

Adorno (2003) não se enquadrou como hermeneuta, mas movimentou-se por um processo hermenêutico sempre em busca constante e revisão de (con)textos sociais para chegar a uma realidade mais justa e interdependente das ações e planos humanos. Adorno (2003, p. 269) identifica caminhos no "detalhe a centelha hermenêutica" para uma relação dialética, a partir da qual se apresentam contradições e complementações, no próprio jogo conceitual da dinâmica histórica. A verdadeira interpretação não busca uma definição acabada e fixa, pois, o significado "[...] é incompleto, contraditório e fragmentário e grande parte dele pode estar entregue a cegos demônios. Talvez a leitura seja precisamente nossa tarefa, para que lendo aprendamos a conhecer melhor e a banir os poderes demoníacos". (Adorno, 2005, p. 7).

Com base nos pressupostos de Freire (2002, p. 83), também buscamos realizar um diálogo emancipador, visto que a conversação é "[...] encontro entre os homens, mediatizados pelo mundo, para designá-lo. Se ao dizer suas palavras, ao chamar ao mundo, os homens o transformam, o diálogo impõe-se como o caminho pela qual os homens encontram seu significado enquanto homens [..]", então, o “[...] diálogo é, pois, uma necessidade existencial". Tal diálogo é tido como um processo de abertura para a compreensão e valorização das diferenças e das múltiplas vozes, possibilitando o avanço interpretativo na conversação (auto)crítica. Contudo, o presente estudo inicia com a historicidade do pensamento de Adorno ante seu exílio e, posteriormente, aborda as posturas críticas de Freire e as influências em sua caminhada. Em cada pensador, apresentamos também seus entendimentos sobre a educação, suas motivações investigativas, constituindo mais um elemento da coerência no sentido de superar os regimentos totalitários. Como culminância, apresentamos uma reflexão que subjaz à vida de ambos, uma vez que tiveram que se exilar para manterem posturas de resistência ao instituído, tal como vemos em exílios com êxodos populacionais e emigrações com deportações nas situações contemporâneas. Esse reconhecimento da condenação ao exílio pela opressão, expulsão e fuga é evidenciado por Arendt (1989, p. 347) como dilema da própria condição humana, em suas palavras, "[...] não ter raízes significa não ter no mundo um lugar reconhecido e garantido pelos outros".

\section{A postura crítica de Adorno frente ao totalitarismo das formas de pensar}

É no contexto da II Guerra Mundial (1939-1945) que o pensamento crítico de Adorno floresce e se revela consistente ante ao fato histórico que marca 
profundamente sua personalidade e pensamento crítico-social, já que a ele e aos outros pensadores da Escola de Frankfurt o exílio se torna a única saída possível. Em busca de refúgio, em 1933, parte então à Inglaterra, onde lecionou na Universidade de Oxford. Todavia, Horkheimer, que estava nos Estados Unidos procurando manter viva a Escola de Frankfurt, convidou Adorno para assumir a coordenação do Princeton Radio Research, em Nova York. Em 1938, aceitando o convite, Adorno se muda para os Estados Unidos, trabalhando no projeto musical e no Instituto de Pesquisa Social (Pucci, 1997). O exílio, enquanto uma realidade severa e impiedosa, vivenciado por ambos os teóricos imersos em uma conjuntura social que acarretou a ruptura de padrões estabelecidos, ocasionou uma nova compreensão de mundo, das diferenças, da alteridade e da própria condição humana. Além disso, permitiu a percepção crítica de que muitas das ações coletivas apresentadas no contexto totalitário do Holocausto não foram oriundas de uma postura pessoal e livre dos sujeitos, mas da imposição e manipulação oriunda de um sistema coercitivo. Perius (2006, p. 17) salienta que,

A iminência da guerra e as perseguições sofridas (por serem judeus), o fracasso da revolução socialista na União Soviética, tornando-a mais um modelo de totalitarismo e de violência e, por fim, a superficialidade da cultura de massas, observada nos EUA na época do exílio, são alguns dos fatores mais determinantes desse olhar crítico e da gênese de conceitos como o de 'totalidade social falsa', 'sociedade administrada' ou, como aparece no texto Dialética do Esclarecimento, 'calamidade triunfal' (triumphalen Unheils).

Entretanto, o exílio não ocasiona apenas o afastamento do sujeito da realidade primeira, mas também o coloca em pleno contato com a nova realidade na qual ele passa a se inserir. Adorno vivenciou, por um lado, a barbárie provocada pelo totalitarismo alemão, e por outro, a influência da cultura de massa sobre os indivíduos nos Estados Unidos. Adorno e Horkheimer, em 1941, partem então para Los Angeles. Foi a partir deste contexto de nazismo e do exílio que juntos redigem sua principal obra, Dialética do Esclarecimento (1944), cunhando o termo de indústria cultural. Os autores entendem que a indústria cultural visa à homogeneização da sociedade e dissemina a banalização da barbárie, pois não é preciso o encontro com o sofrimento e a dor alheia, apenas que aceitemos e consumamos o que a nós é friamente arquitetado. Na perspectiva da indústria cultural, o desejo de consumo se sobressai ao valor da vida, sendo, muitas vezes, destruída a alteridade e inexistente o respeito à diversidade e à pluralidade humana. Em sua lógica de mercado (caracterizada pelo consumo exacerbado, pela cultura do descarte e da produção de uma nova necessidade), promove uma postura acrítica e massificada frente ao mundo.

Frente a essas realidades, Adorno aprimora a questão da dialética negativa, que se refere à crítica à positividade sintética presente na dialética inaugurada por Platão e 
que encontra em Hegel seu representante principal. Assim, a impossibilidade de síntese é o que marca a dialética adorniana, somada ao fato de que, nessa matriz teórica, a realidade não se identifica com o conceito e por isso é negativa. A partir daí, manifestou em seus escritos a necessidade de uma educação que seja autocrítica e emancipadora, como uma das formas para que a barbárie humana não se repita, anunciando assim, a reeducação como o último reduto possível frente ao império da indústria cultural. Entretanto, o exílio de Adorno não se deu somente por posicionar-se criticamente ante às atrocidades cometidas pelo estado nazista, mas também por ser judeu. Em Adorno vemos um inimigo do sistema Nazista, já que a sua procedência etnorreligiosa o colocava em posição de risco. Assim, em alguns de seus aforismos publicados em sua obra biográfica, Mínima Moralia (primeira publicação em 1951), vemos relatos dos sentimentos oriundos de uma experiência de exílio - Reflexões de uma vida mutilada, que apesar de sua negatividade, por obrigá-lo a se refugiar em outra nação, permite romper fronteiras e analisar a situação social alemã sob uma nova perspectiva. Para Ribeiro (2011, p. 154),

Assim, para Adorno, colocar-se fora de casa é o imperativo moral para que se proceda à constatação de que "todas as avaliações são falsas", que jamais se daria se não no exílio, a morada, por excelência do intelectual, ou melhor, sua não-morada, seu desabrigo, a frenética alternância do olhar e a conquista de outro ponto de vista capaz de ver o que comumente não se via. O preço a se pagar é o de uma vida austera, sem facilidades. Seu olhar diferenciado é fruto unicamente de sua experiência de vida radicalmente prejudicada.

A partir da dimensão empírica, Adorno entende que necessitamos resistir individualmente contra a barbárie, no caso provocada pelo partido nazista e que ocasiona atos violentos, exílios, ondas de massas e de fanatismos em nome da autoridade e do convencimento pela palavra (de Hitler), de modo que o sofrimento alheio recaia na indiferença humana. Adorno (1993, p. 10) diz: "[...] em face da concórdia totalitária que apregoa imediatamente como sentido a eliminação da diferença, é possível que, temporariamente, até mesmo algo da força social de libertação tenha-se retirado para a esfera individual". Tal perspectiva anuncia e considera a morte do que estamos vivendo conscientemente pelo isolamento que destrói a nossa capacidade de agir voltada para o bem comum da vida em sociedade. Em seu aforismo Opinião de diletante, Adorno (1993, p. 70) afirma que "[...] a barbárie é realmente o todo e triunfa ainda sobre o seu próprio espírito", pois constata que a violência destrói a vida humana e contrasta com uma ética da alteridade.

O caráter de coisificação do ser e de resignação para com o fascismo ou a ordem totalitária, claramente explícita no Holocausto, levou a humanidade à degradação, mas essa precisa ser convertida atualmente em possibilidade de análise e percepção daquilo que jamais pode voltar a acontecer. As violências cometidas e sofridas nos campos de concentração no contexto da II Guerra Mundial, segundo Adorno, não podem ser 
esquecidas para que não corramos o risco de repetir tal desumanização. O sentimento negativo de Adorno, fruto de um contexto de exílio, frente a uma sociedade acabada pelo fascismo, sobrevive no desejo de mudança e de repressão de qualquer forma de violência contra a humanidade. As circunstâncias de exílio acometidas a Adorno conduziram-no a responder com reflexões duras contra os preconceitos, indo muito além de um benefício pessoal, mas buscando um engajamento e amadurecimento social em vista da erradicação das violências e barbáries que deterioram a existência humana pelo desejo de poder para dominar o outro e o mundo. Ribeiro (2011, p. 171) reforça que,

O olhar do deslocado como descreve Adorno em Mínima Moralia expressa um ganho ao pensamento crítico se o intelectual exilado consegue manter-se austero em face de um redemoinho de pessoas, lugares, ambientes, apelos, aparências, ameaças, facilidades, inadaptações, negociações nas quais se vê envolvido. A perspectiva crítica, a reserva intelectual, a coragem moral são virtudes potentes a serem cultivadas pelo pensador no exílio.

Adorno (1995) foi categórico ao enfatizar que a única forma de esclarecimento das consciências contra a barbárie, para que Auschwitz não se repita, precisa ser uma atitude dirigida e coordenada pela educação no contexto das massas populares. Vale mencionar que Auschwitz foi uma regressão humana, pois se constituiu de mecanismos como a frieza, a repressão do medo, a dominação, a crueldade, a dureza de vida que foram características dos campos de concentração. Auschwitz representou uma espécie de racionalização instrumental centralizada pelos meios bárbaros despertados por ela mesma. Uma identidade autorreferente, não produtiva, porque é baseada na fraqueza do eu para o tempo, na história e no espaço, na reação ao diferente.

Adorno colaborou para desvendar os determinantes da limitação do esclarecimento, da experiência do insucesso da humanização do mundo, da generalização da alienação e da dissolução da experiência formativa. Tal análise revela que as relações sociais não afetam apenas as condições da produção econômica e material, mas também interagem no plano da "subjetividade", onde originam relações de dominação. Adorno e Horkheimer tecem uma crítica ao identificar que, enquanto promessa, o esclarecimento, tendo como guia a razão, fracassou e conduziu-nos às mais catastróficas barbáries.

No sentido mais amplo do progresso do pensamento, o esclarecimento tem perseguido sempre o objetivo de livrar os homens do medo e de investi-los na posição de senhores. Mas a terra totalmente esclarecida resplandece sob o signo de uma calamidade triunfal. O programa do esclarecimento era o desencantamento do mundo. Sua meta era dissolver os mitos e substituir a imaginação pelo saber. (Adorno; Horkheimer, 1985, p. 13). 
Dessa forma, pessoas que se enquadram cegamente em coletivos convertem a si próprios, aquilo que Adorno denominou como "caráter manipulador", que é a incapacidade de levar a cabo experiências humanas, pela ausência de emoções. $\mathrm{Na}$ relação atual com a técnica, os homens ao mesmo tempo em que progridem podem regredir num irracionalismo patogênico. Para Adorno, se as pessoas não fossem profundamente indiferentes em relação ao que acontece com todas as outras, então Auschwitz não teria sido possível, as pessoas não o teriam aceitado. Adorno coloca a educação como um meio para desbarbarizar a sociedade, tendo seu pleno sentido quando dirigida a uma autocrítica. Afirma que a exigência que Auschwitz não se repita é primordial no sentido de que a educação se torna significativa quando trabalha com a inconsciência dessa agressividade, esclarecendo os mecanismos repressivos a partir da autorreflexão e da problematização do existente. Segundo Adorno (1995, p. 142), a educação após Auschwitz se encarregaria de duas questões básicas para que não recaísse na barbárie, a saber: a educação infantil, sobretudo na primeira infância; e o esclarecimento geral, que produz um clima intelectual, cultural e socialmente libertador da "produção de uma consciência verdadeira".

Coerente com sua filiação à teoria crítica, Adorno ${ }^{2}$ teria revelado seu posicionamento a favor de uma tarefa da escola orientada para a formação de sujeitos com capacidade de autonomia (expressão kantiana) de pensamento e de ação. Entender o que Adorno via no sistema de ensino daquele tempo não é apenas ver sua crítica a uma instituição que propagava os sistemas de dominação na sociedade capitalista. Mas também compreender a visão do autor, sustentada pela perspectiva de escola como a instituição social capaz de formar e reeducar o homem das amarras da dominação inerentes à ordem capitalista. Contudo, a única concretização efetiva de emancipação consiste em que aquelas poucas pessoas interessadas nessa direção orientem toda a sua energia para que a educação aconteça a partir da contradição e da resistência aos dispositivos de controle, que asseguram a reprodução do desprezo social já existente. Sem sombra de dúvidas, "[...] a nossa política não conhece hoje outro valor (e, consequentemente, outro desvalor) que a vida, e até que as contradições que isto implica não forem solucionadas, nazismo e fascismo, que haviam feito da decisão sobre a vida nua o critério político supremo, permanecerão desgraçadamente atuais". (Agamben, 2004, p. 18).

2 Após dezesseis anos de exílio, Adorno e Horkheimer retornaram à Alemanha e reconstituíram o Instituto de Pesquisa Social em seus fragmentos, uma vez que se encontrava destroçada e destruída. Adorno faleceu em 1969, na Suíça, mas deixou um vasto legado na reflexão crítica contra a barbárie e contra uma sociedade massificadora, que coisifica o ser pela ausência de emoções e pela indiferença à alteridade. 


\section{A ditadura militar e o autoritarismo na perspectiva de Paulo Freire}

A Ditadura Militar do Brasil ocorreu de 1964 a 1985, momento em que os militares governaram o país, caracterizada pela ausência de democracia, destruição dos direitos constitucionais, censuras, perseguições políticas e sentenças aos que eram contrários ao autoritarismo, deixando estragos no sistema educacional e na história nacional. No período de 1930 a 1964, Paulo Freire, nascido em 19 de setembro de 1921 em Recife, Pernambuco, se destacou entre os intelectuais brasileiros, tornando-se reconhecido no governo do Presidente João Goulart por ter coordenado o Programa Nacional de Alfabetização (PNA, em 1962). Freire elaborou os alicerces de seu raciocínio sempre ligado ao contexto sociopolítico brasileiro, vigilante às dificuldades da população, principalmente na busca de respostas democráticas voltadas aos oprimidos enquanto atitude crítica frente ao mundo.

Esse trabalho intelectual em prol dos mais necessitados foi obstruído pelo Golpe Militar de 1964, pois mobilizava a classe oprimida a lutar por seus direitos e liberdade de expressão. Tal ato, frente a uma época de enfrentamentos na história do Brasil, culminou no exílio de muitos intelectuais, bem como, de Paulo Freire. Através do golpe de estado, "[...] os ideais políticos advindos do PNA foram imediatamente suspensos, seus/suas mentores/as procurados/as, tendo seus direitos constitucionais caçados e, muitas vezes, sendo exilados/as, como foi o caso de Paulo Freire". (Silva, 2011, p. 51). Neste contexto, a sociedade capitalista brasileira apresentava-se uma sociedade

[...] fechada a que já nos referimos. Sociedade, acrescente-se, com o centro de decisão de sua economia fora dela. Economia, por isso mesmo, comandada por um mercado externo. Exportadora de matérias primas. Crescendo para fora. Predatória. Sociedade reflexa na sua economia. Por isso alienada. Objeto e não sujeito de si mesma. Sem povo. Antidialogal, dificultando a mobilidade social vertical ascendente. Sem vida urbana ou com precária vida urbana. Com alarmantes índices de analfabetismo, ainda hoje persistentes. Atrasada. Comandada por uma elite superposta a seu mundo, ao invés de com ele integrada (Freire, 2009, p. 57).

Visando a não findar suas críticas que emergiam de uma realidade degradante, em prol de um povo oprimido por um sistema totalitário de governo, em junho de 1964, antes de ser preso pela primeira vez, Freire solicitou permissão no passaporte para viajar ao México. Porém, a solicitação foi recusada pelos políticos que invalidaram seus direitos, alegando que seus estudos eram extremamente esquerdistas ao privilegiar os mais necessitados. Na primeira prisão, Freire permaneceu por vinte dias, sendo solto no dia 3 de julho. Na segunda prisão, ficou preso por cinquenta dias, passando por diversos presídios de Recife e Olinda. Quando solto, Freire viajou ao Rio de Janeiro onde pediu acolhimento na Embaixada Boliviana e chegando a La Paz com seus familiares em outubro de 1964. Porém, ficou menos de dois meses, pois um novo golpe de Estado 
o atacou, precisando se exilar no Chile. Durante o exílio no Chile, escreveu o livro Pedagogia do Oprimido. No período de abril de 1969 a fevereiro de 1970, Freire lecionou nos Estados Unidos na Universidade de Harvard. Posteriormente, no período de 1970 a 1980, exilou-se em Genebra, Suíça. A partir de 1975, quando conheceu Guiné-Bissau (África), Freire trabalhou mais diretamente na África, especificamente em Cabo Verde, Angola, São Tomé e Príncipe, que estavam em um período de reconstrução pela conquista da independência. Só retornou ao Brasil no final de 1980. Por estes caminhos, Freire (2003, p. 34) escreveu sobre a experiência do exílio:

Na verdade, um dos sérios problemas do exilado ou exilada está em como lidar, de corpo inteiro, com os sentimentos, desejos, razão, recordação, conhecimento acumulados, visões de mundo, com a tensão entre o hoje vivido na realidade de empréstimo e o ontem, no seu contexto de origem, de que chegou carregado de marcas fundamentais. No fundo, como preservar sua identidade na relação entre a ocupação indispensável no novo contexto e a pré-ocupação em que o de origem deve constituir-se. Como lidar com a saudade sem permitir que ela vire nostalgia.

O exílio marcou profundamente suas reflexões. Paulo Freire, mesmo com tamanha capacidade intelectual, não teria tal abordagem questionadora da realidade sem a experiência do exílio. Suas críticas e manifestações adquiriram forma e consistência na medida em que esteve inserido nos contextos de expatriação. Por isso, publicou diversas obras que refletiam suas experiências no Brasil e suas vivências nômades de exilado político. Da vivência comprometida com os oprimidos, Freire construiu suas reflexões percebendo as incoerências e obstáculos do processo emancipador e os mecanismos de dominação e de poder, para manter a opressão em relação aos dominados. Freire provocou hipóteses transformadoras sobre a práxis social crítica mediada pelo diálogo, articulando as dimensões objetiva, subjetiva e social da racionalidade educativa, pela capacidade de leitura crítica de mundos e pela abertura realizada num contexto sociocultural com os outros (marginalizados e oprimidos).

Na concepção freireana, é através da relação de diálogo que se inicia o ato de ensinar e de aprender com atividades participativas de pesquisa e de (re)elaboração própria e coletiva nas quais podemos ser autônomos e motivados a (re)conhecer ações, interpretações, como atores do conhecimento social. A autonomia faz parte dos processos educativos e formativos, ao lado da capacidade de (auto)crítica, de ajudar os estudantes a desenvolverem o gosto de fazer leituras, interpretações e relações com os outros. Esse diálogo não pode reduzir-se a uma postura de impor ideias ou apenas trocá-las, ou seja, "[...] o diálogo não pode converter-se num bate-papo desobrigado que marche ao gosto do acaso entre professor ou professora e educandos. O diálogo pedagógico implica tanto o conteúdo ou objeto cognoscível". (Freire, 2003, p. 118).

Mas em uma sociedade opressora, como no seu contexto de exílio, as possibilidades de diálogo são atrofiadas ou diminuídas em informações desconexas e sem sentido, pois só ocorre "[...] entre iguais e diferentes, nunca entre antagônicos". (Freire, 2002, p. 
123). A ideia da educação problematizadora estimula nos estudantes a capacidade de (re)pensar através de problematizações e contextualizações, de buscas por respostas diferentes à educação tradicional chamada por Freire de bancária, de saberes prontos, com perguntas e respostas lineares, não possibilitando novos e diferentes significados e sentidos. A problematização pode partir do professor e do estudante, porém precisa ser retroalimentada para o aperfeiçoamento das performances, mas sempre em profícuos diálogos com as diferenças.

Para Freire, o diálogo surge do encontro com o outro, e este não vive sem tal prática, já que o diálogo humaniza e o torna crítico no mundo em que habita, podendo desta forma transformá-lo, pois não há transformação nem novos entendimentos sem a conversação. O diálogo tem algo de libertador e contribui para a emancipação do agir intersubjetivo. A educação contribui para a formação de sujeitos críticos, pensantes, pois instiga os participantes a questionar o mundo, perceber a condição humana de inacabamento e de necessidade de buscar a melhoria da vida social. A pessoa crítica é a que será geradora de mudanças no mundo, pois ao aperfeiçoar sua criticidade deixa de ser um indivíduo semiformado e passa a ser um sujeito questionador das desigualdades na sociedade em que vive, já que percebe sua condição de oprimido. Freire (2002) desenvolve uma pedagogia social e crítica, contribuindo para os processos de desalienação intersubjetiva.

Para Freire (2001, p. 31), "[...] é bem verdade que a industrialização vem promovendo a sua transformação de espectador quase incomprometido em 'participante' ingênuo, em grandes áreas da vida nacional". A partir da vivência do exílio, assumiu uma relação de diálogo crítico, que implica na percepção do condicionamento histórico-sociológico e ideológico, diante de uma prática pedagógica autoritária e opressora, contribuindo com a formação de ações educativas justas e problematizadoras da realidade. A compreensão de sua visão crítica é assim radicalizada: "[...]o meu discurso em favor do sonho, da utopia, da liberdade, da democracia é o discurso de quem recusa a acomodação e não deixa morrer em si o gosto de ser gente, que o fatalismo deteriora". (Freire, 2001, p. 86).

Freire dedicou grande parte de sua vida ao reconhecimento da educação para uma sociedade emancipada, bem como no combate às formas de pedagogia bancária, excludentes, preconceituosas e elitistas. Suas reflexões tiveram incidência na sociedade brasileira na época de transição para a modernização, onde as disputas pelo poder político estavam centradas em duas grandes forças: urbano-industrial e agrocomercial. Estas foram as bases de 1955 a 1965 que propunham uma ideologia da consciência nacional, sugerindo o desenvolvimento do país. Paulo Freire expõe que é necessário aumentar o grau de atuação política do povo sobre as questões que acontecem no âmbito social, enquanto seres voltados à construção emancipatória. Para isso, sugere como potencial do círculo de cultura, pois em cada âmbito social existem temas geradores para serem discutidos, destacando-se a compreensão pela 
leitura crítica dos clássicos, não como simples repetição, mas como participação no presente, alargando horizontes de conhecimento do período histórico e do contexto social. Para que o círculo de cultura vingasse, era preciso realizar pesquisas através de temas geradores com conversas informais com os moradores da localidade, em que "[...] dirão o porquê, e como e o para que da investigação que pretendem realizar e que não podem fazê-lo se não se estabelece uma relação de simpatia e confiança mútuas". (Freire, 2002, p. 121). Os pesquisadores em seus diálogos com a população acionam um olhar crítico, recolhendo subsídios para a compreensão dos modos de vida, de ser e de pensar dos sujeitos, a fim de que juntos possam tecer a sua descodificação através de uma visão crítica, reflexiva, relacional e observadora da própria realidade.

Ao invés de manifestar uma perspectiva fatalista ou de acomodação intelectual em relação ao exílio, Freire luta e desenvolve nesta experiência uma sensibilidade, generosidade e solidariedade aos diferentes contextos, tornando-se um educador mundialmente reconhecido por promover uma cultura do diálogo mediante a conscientização. A partir do diálogo intercultural, Freire conseguiu (re)aprender, questionar e dizer a própria palavra, pois "[...] foi por esses pedaços de mundo, como exilado, que pude compreender melhor o meu próprio país. Foi vendo-o de longe, foi tomando distância dele que eu entendi melhor a mim mesmo" (Freire; Faundez, 1985, p. 22). Freire (2002, p. 38) afirma que é a "[...] reflexão e a ação dos homens sobre o mundo que faz a transformação acontecer, sem esses dois atos a superação da condição opressor e oprimido é impossível". Said (2003, p. 58) destaca que,

O exilado sabe que, num mundo secular e contingente, as pátrias são sempre provisórias. Fronteiras e barreiras, que nos fecham na segurança de um território familiar, também podem se tornar prisões e são, com frequência, defendidas além da razão ou da necessidade. $\mathrm{O}$ exilado atravessa fronteiras, rompe barreiras do pensamento e da experiência.

O exílio trouxe sofrimento para Freire, mas também experiências que o enriqueceram como intelectual da classe trabalhadora nas instituições de diferentes países, cultivando assim uma forma de ensinar e de aprender que humaniza por meio da reflexão e da prática social, denunciando as falsas fronteiras do conhecimento. Freire destaca que as massas oprimidas devem se introduzir criticamente no meio através da práxis, o que induzirá o sujeito a ser sujeito da história, pois "[...] transformar a realidade opressora é tarefa histórica, é tarefa dos homens". (Freire, 2003, p. 41).

Freire (2002, p. 93) afirma que "[...] se alguém não é capaz de sentir-se e saber-se tão homem quanto os outros, é que lhe falta ainda muito que caminhar para chegar ao lugar de encontro com eles". Nos espaços de encontro, nos círculos de cultura ou através do dialógico, "[...] não há ignorantes absolutos, nem sábios absolutos: há homens que, em comunhão, buscam saber mais" (Freire, 2002, p. 95). O pensador destaca que não existe diálogo sem a amorosidade do falar e do ouvir o outro, pois é da linguagem que nasce o saber, que está na capacidade de decodificar e examinar os fatos do mundo 
de forma aventureira e investigativa. Assim, "[...] se não amo o mundo, se não amo a vida, se não amo os homens, não me é possível o diálogo". (Freire, 2002, p. 92). Para o diálogo acontecer é necessário despertar e potencializar nos sujeitos a capacidade de (re)inventar como um artifício constituinte antes de qualquer diálogo. Sujeitos dialógicos e com a capacidade crítica sabem que podem transformar-se mutuamente. De acordo com Freire (2002, p. 94), "[...] ao fundar-se no amor, na humildade, na fé nos homens, o diálogo se faz uma relação horizontal, em que a confiança de um polo no outro é consequência óbvia. Seria uma contradição se, amoroso, humilde e cheio de fé, o diálogo não provocasse este clima de confiança entre seus sujeitos".

O diálogo também abre possibilidades para a utopia esperançosa, visto que não há diálogo sem a esperança que acompanha a busca de mudanças para a melhoria da vida em sociedade. Nas palavras de Freire (2002, p. 95), "[...] movo-me na esperança enquanto luto e, se luto com esperança, espero", não de forma ilusória, pacífica e receptora, mas com a disposição de saber debater proposições e reconstruílas permanentemente conforme as necessidades, por meio da geração de uma reflexividade que provém do outro (nem sempre disponível), pois, "[...] não há o diálogo verdadeiro se não há nos seus sujeitos um pensar verdadeiro". A capacidade de diálogo é a abertura ao olhar do outro, à inquietação e à curiosidade de aprender e evoluir com o outro, indo além da uniformização ou homogeneização das consciências, "[...] porque os sujeitos dialógicos não apenas conservam sua identidade, mas a defendem e assim crescem um com o outro. O diálogo, por isso mesmo, não nivela, não reduz um ao outro. Nem é favor que um faz ao outro". (Freire, 2003, p. 118).

\section{Considerações finais}

Adorno e Freire vivenciaram o exílio em períodos, locais e por ocasiões distintas, mas ambos viveram tempos de inquietações e incertezas, desenvolvendo suas críticas contra regimes totalitários que assolavam suas pátrias, contra a identificação cega pelo coletivo, o poder dominador de manipular e homogeneizar da cultura e a favor de uma consciência verdadeira. Cabe ressaltar que esses intelectuais apresentam realidades e conjunturas políticas e sociais diferentes entre o contexto da Segunda Guerra e a Ditadura Militar, no Brasil, bem como concepções de educação e emancipação com diferenças significativas entre ambos. No entanto, convergem no que diz respeito à educação como forma de promover o esclarecimento coletivo. Adorno trata da crítica à sociedade administrada, da coisificação do ser e da cultura a ser superada pela educação, enquanto Freire aborda a emancipação política que a escola potencializa no sentido da superação do estado de opressão.

Segundo Adorno, para superar as questões desagregadoras e os tempos sombrios da sociedade (marcados pela dor e injustiça), é preciso manter-se aberto, com todos os 
sentidos, todos os sentimentos de amor que nos une, para o discurso alheio, livre e de maneira plural. Para Freire, a educação é um caminho para conduzir o ser humano à emancipação, pela impossibilidade de neutralidade da prática educativa, que demanda a compreensão da significação profunda da palavra na práxis social e pelo diálogo entre prática e teoria à educação libertadora do sentido educativo e humano.

Por fim, "[...] tanto Adorno quanto Freire combatiam a sociedade capitalista de seu tempo e ambos os autores se posicionavam contra a alienação do homem; logo, a emancipação humana foi preocupação comum" (Mashiba, 2013, p. 8). Este movimento do pensar os exílios tornou-se um ato humanamente revolucionário (a favor da vida) e de luta contra a violência porque reconheceu os fatos que foram apagados pela tradição cultural que desconsidera a condição das vítimas e valoriza os vencedores. Adorno e Freire abrem diante de nós perspectivas de reconstrução epistemológica, política, cultural e social por meio da educação, frente ao pensamento homogeneizador da cultura, possibilitando o reconhecimento dos mecanismos aprisionadores da vida uma vez que o exílio implica ruptura de absolutismos, assim como questionamentos da realidade.

Portanto, esses autores, após vivenciarem suas experiências de exílio, colocam a educação como um meio para desbarbarizar a sociedade, tendo seu pleno sentido quando dirigida a uma autocrítica (como substancial no movimento de superação da barbárie), a partir do diálogo, da autorreflexão e da problematização do existente. Assim, a formação de uma consciência crítica acontece a partir da contradição e da resistência, como um caminho para ser livre e manter-se aberto, com todos os sentidos e sentimentos, para o discurso alheio, que reconhece a pluralidade de percepções da realidade. Enfim, a única coisa que precisamos manter viva, sem exilar na educação, é a capacidade de pensamento reflexivo, relacional e a conversação com a diversidade e a pluralidade sociocultural, sob pena de aniquilar e alienar as potencialidades da vida e da criação humana. Estamos em permanente luta por justiça social e direito à liberdade, por meio da experiência educativa como forma de exercer uma vida criadora na invenção do cotidiano, para não recairmos em ações de desenraizamento populacional de exilados, com a sensação de mudez, do indizível, da fragmentação da memória e da instabilidade angustiante. Para evitar que os direitos humanos básicos não sejam exterminados na retórica capitalista por estados totalitários veiculados, inclusive pela falsidade das informações espetaculares, cabe recuperar o poder comunicativo da educação. 


\section{Referências}

ADORNO, Theodor Ludwig Wiesengrund. (1995). Educação e Emancipação. Rio de Janeiro: Paz e Terra.

ADORNO, Theodor Ludwig Wiesengrund. (1993). Mínima moralia: reflexões a partir da vida danificada. Trad. Luiz Eduardo Bica. 2. ed. São Paulo: Ática.

ADORNO, Theodor Ludwig Wiesengrund. (2005). A atualidade da filosofia. Primeira Versão, Porto Velho, Ano IV, n. 195, p. 2-12. Disponível em: <http://www. primeiraversao.unir.br/atigos_pdf/195_.pdf>. Acesso em: 15 jun. 2018.

ADORNO, Theodor Ludwig Wiesengrund; HORKHEIMER, Max. (1985). A Dialética do Esclarecimento. Rio de Janeiro: Jorge Zahar.

AGAMBEN, Giorgio. (2004). Homo Sacer. O poder soberano e a vida nua I. Trad. Henrique Burigo. Belo Horizonte: Editora UFMG.

ARENDT, Hannah. (1989). Origens do totalitarismo. Trad. Roberto Raposo. São Paulo: Companhia das Letras.

BENJAMIN, Walter. (1994). Obras escolhidas I: magia e técnica, arte e política. São Paulo: Brasiliense.

FREIRE, Paulo. (2001). A educação na cidade. 5. ed. São Paulo: Ed. Cortez.

FREIRE, Paulo. (2003). Pedagogia da Esperança: um reencontro com a Pedagogia do Oprimido. 11. ed. São Paulo: Paz e Terra.

FREIRE, Paulo. (2002). Pedagogia do oprimido. 34. ed. Rio de Janeiro: Ed. Paz e Terra.

FREIRE, Paulo. (2009). Educação como prática da liberdade. Rio de Janeiro: Paz e Terra.

FREIRE, Paulo; FAUNDEZ, Antonio. (1985). Por uma pedagogia da pergunta. Rio de Janeiro: Paz e Terra.

MASHIBA, Glaciane Cristina Xavier. (2013). Emancipação humana em Theodor Adorno e Paulo Freire. 2013. 150 f. Tese (Doutorado em Educação) - Universidade Estadual de Maringá, Maringá.

PERIUS, Oneide. (2006). Esclarecimento e dialética negativa: sobre o além-doconceito em Theodor Adorno. 2006. 113 p. Dissertação (Mestrado em Filosofia) - Pontifícia Universidade Católica do Rio Grande do Sul, Porto Alegre. 
PUCCI, Bruno. (1997). Filosofia negativa e Educação: Adorno. Filosofia, sociedade e educação, Marília, v. 1, n. 1, p. 163-192.

RIBEIRO, Adelia Maria Miglievich. (2011). Intelectuais no exílio: onde é a minha casa? Dimensões, v. 26, p. 152-176.

SAID, Edward. (2003). Reflexões sobre o exílio e outros ensaios. Trad. Pedro Maia Soares. São Paulo: Companhia das Letras.

SILVA, Alexandre Rodrigo Nishiwaki da. (2011). Conhecimento e conscientização: a historicidade do pensamento de Paulo Freire. 2011. 142 f. Dissertação (Mestrado em Ciências Humanas) - Universidade Federal de São Carlos, São Carlos.

SZNITER, Célia. (1996). A Dimensão Visual da Propaganda Nazista: as imagens do judeu e do ariano. 1996. 175 p. Dissertação (Mestrado em Letras Orientais) Universidade de São Paulo, São Paulo.

Adilson Cristiano Habowski é Mestrando em Educação da Universidade La Salle UNILASALLE, Canoas. Bolsista da CAPES. Integrante do grupo de pesquisa NETE/CNPq.

Elaine Conte é Doutora em Educação (UFRGS). Professora do Programa de PósGraduação em Educação da Universidade La Salle - UNILASALLE/Canoas. Líder do Núcleo de Pesquisas sobre Tecnologias na Educação - NETE/CNPq e membro do Grupo de Estudos sobre Filosofia da Educação e Formação de Professores - GEFFOP/CNPq. 